\title{
Editorial: Between Breaths
}

\author{
FINTAN WALSH
}

Riding the waves of a pandemic, following weeks of protest, we're all desperate to exhale. You feel it in the coiled air, the strained tone of students' emails, frustrated conversations across Zoom. In the tense queues lining grocery stores, you can sense it too; among the self-policing postures of pedestrians and passengers. When will all this be over? Where do we find relief?

Breathe in and out slowly, the mindfulness guides advise, yielding anxiety to inner peace. But these mantras meet their limit when breathing itself has become the problem - a vaporous stage of ecological, medical and political battle. For as we have seen in the overlapping tumult of COVID-19 and Black Lives Matter demonstrations, to breathe or not to breathe-when, where and how-have become some of the most pressing questions of the year, affecting how we conduct our intimate and public lives. But for many, these are not personal choices but obligations and enforcements, decided by economic necessity or governmental rule. Who gets to breathe at all, in this toxic atmosphere, and what are the consequences, if any, for those who would deprive another of that right?

The global coronavirus pandemic and the killing of George Floyd in Minneapolis under police chokehold-whose dying words 'I can't breathe' propelled the most recent round of Black Lives Matter protests-are among two of the most defining events of the past few months. While these phenomena are not reducible to one another, their coinciding has generated scenes of singular power, in part arising from the seemingly oppositional nature of the imagery produced: socially-distanced protest; masked oratory; cries to be let freely breathe swallowed by clouds of tear gas and pepper spray. While rooted in the brutal killing of African American men, these pleas seemed also to speak to the disproportionate death of people of colour due to COVID-19, as well as an appeal to those unwilling to wear face coverings at all to prioritize social protection over a more selfish notion of individual choice.

Struck by some of these strange intersections at a Black Lives Matter gathering in central London in June, I found myself thinking about the prescience of Arinzé Kene's Misty, which I had seen in Trafalgar Studios in 2018. Part grime gig, part theatre performance, Kene depicts London as a city where black people are treated like viruses, feared by white people and tracked by police. But his work ultimately explores the way racist political imperatives are used to frame people of colour in this way, to keep them out of their neighbourhoods, their cities, their country, and to deprive them of material resources. Racism and disease are intimately connected in Kene's play, not unlike how they have found themselves intertwined in recent months. But racism is the primary cause of ruin in Kene's world, fostering pathogenic 
projections to justify an assault on ethnic communities. 'I can breathe,' Kene's central character reflects at one point, 'But fear that any moment someone's coming to suffocate me'. ${ }^{1}$ Eventually the police do just this: 'Struggling to breathe...they're folding me like a long sleeve...My ears pop....Everything stops'.

The articles in this issue of Theatre Research International are held between breaths that sharpen focus on scenes of cultural exchange and refusal. In the first contribution, Emma Welton evokes the image of our imperiled neighbours straining to stay afloat at sea, while in the last section, devoted to Phillip Zarrilli, who died in April of this year, we are reminded of the centrality of breath to his understanding of the creative process. In between these articles, authors explore some of the ways in which theatre functions to oxygenate intercultural dialogues, revive canonical plays, and how even apparently inanimate theatrical remains pulse with life.

In 'Welcome to The Jungle: Performing Borders and Belonging in Contemporary British Migration Theatre', Welton considers Good Chance Theatre's production of The Jungle, which dramatized events at the Calais refugee and migrant camp. Originally a Young Vic production, Welton's article focuses on its West End iteration, to question the work's insistence on physical intimacy, immersion and comedy to allow audiences to feel empathic. For Welton, invoking a Brechtian train of thought, these strategies commodify the horrors of refugee experience, rather than allow for more meaningful critical engagement. One of the questions Welton's article raises is how can theatre dramaturgies and design honour not only the spaces that connect us, but the oceans we willfully allow to divide us?

Peilin Liang's article brings her experience of leading an applied theatre project, which explored ideas of home and belonging, with marriage migrants living in Taiwan, including Singapore-based practitioners. In 'Towards a Collaborative Ergonomics: From Strangers to Symbiotic Community through Boundary Traversal in Performance', Liang proposes the idea of 'collaborative ergonomics' as a way to account for the design features developed to support the cultural interactions that comprised her project. Collaborative design practices, Liang argues, offer fresh ways for organising and understanding intercultural performance, capable of offering support even beyond the act of artistic creation.

While Liang stresses the value of managing intercultural encounters, Min Tian cautions against the over-inflation of intercultural myths. In 'Mei Lanfang and Stanislavsky: The (De)construction of an Intercultural Myth on the International Stage', Tian debunks stories of Stanislavsky's deep engagement with the famous Chinese actor Lanfang, said to have had a transformative impact on Chinese theatre. Challenging largely unquestioned stories, Tian argues that established myths were built on strategic attempts to politically and ideologically connect China with Soviet Russia in the 1950s, rather than sustained artistic interchange.

The novel staging of classics is often described as breathing new life into an inert artefact. In 'Staging Tagore Beyond the Spectres of Authority: Suman Mukhopadhyay's Falguni: Suchana (2001)', Rajdeep Konar discusses the theatre of Rabindranath Tagore, and the ways in which his artistic control has stalled his works from evolving. Konar explores how this has come to be, while also analysing how 
Mukhopadhyay's Falguni: Suchana was a pivotal production in the subversion of Tagore's authority, freeing up his oeuvre to further interpretation.

While Konar is concerned with the inertia of sanctified theatre works, in the dossier 'Theatrical Vestiges: Material Remains and Theatre Historiography' contributors suggest that there is no such thing as a dead theatrical object at all. T. Sofie Taubert and Ruthie Abeliovich unite colleagues to discuss the powerful agency of theatrical remains, and their capacity for vitality long after a live event. The articles consider how material objects enliven and reorient the concerns and approaches of theatre historiography, reminding us that even breathless objects have force, retaining the capacity to inspire.

Inspired by Asian martial and meditation arts, Zarrilli's work was devoted to making, teaching and understanding intercultural performance encounters. The phenomenological experience of breath was central to Zarrilli's idea of the actor's craft, and a means to undo Western ideas of bounded psychology and selfhood. Among a range of guiding principles, the importance of breath and breathing to Zarrilli's work recurs in the entries included in this issue to mark his enormous contribution to our field, relayed by students, colleagues, collaborators and friends.

Zarrilli returned to the work of Samuel Beckett, whose Breath (1969) features a brief cry, which begets a breath, which carries mere moments of theatrical illumination. In this minimalist work, Beckett seems to be distilling a cycle of life, while proposing that, when all else is stripped away, perhaps what's fundamental to both life and theatre is breath. 'Inspiration' and 'expiration' are the words Beckett uses to describe the breathing process, terms that capture the connection between inhalation and creativity, exhalation and death. 'For the actor to conspire,' Zarrilli tells us, 'he must in-spire....and...ex-pire...suspended between the in-spiration and ex-piration the actor finds her way to the "edge of the breath" where thought and action hang in the balance. ${ }^{4}$ Creative production, we might say, hangs in the balance of exchanging breath.

The articles in this issue are varied in their individual concerns, but as we approach them from this point in time, we might reflect on some of the real and metaphorical ways in which breathing has become an urgent personal and political matter, which exposes the fundamental interdependency of our lives-your breath is mine, mine is yours. And given Beckett's stage direction that breath should be recorded, rather than live, during this time of widespread theatre closure we may decide, for now at least, that we are not bound to face-to-face encounters for inspiration. Instead, we may turn to those sensations that ventilate our memories, imagined futures, pages and screens, reminding us of all that we must share but cannot own, and the ethical stakes of this primal contract with life.

NOTES

Arinzé Kene, Misty (London: Nick Hern Books, 2018), p. 48.

Ibid., p. 65.

See 'Breath' in Samuel Beckett, Krapp's Last Tape and Other Shorter Plays (London: Faber and Faber Ltd, 2009), pp. 77-8o.

4 Phillip B. Zarrilli, 'The Metaphysical Studio', TDR: The Drama Review, 46, 2 (Summer 2002), pp. 157-70, here p. 168. 